\title{
EPIDERMAL MICROMORPHOLOGY OF HORDELYMUS EUROPAEUS (L.) JESS. EX HARZ (POACEAE)
}

\author{
MaŁgorzata Klimko, Renata Nowińska, Aneta Czarna \\ M. Klimko, R. Nowińska, A. Czarna, Department of Botany, Poznań University of Life Sciences, Wojska \\ Polskiego 71 C, 60-625 Poznań, Poland, e-mail: klim@up.poznan.pl,nowinska@up.poznan.pl, czarna@ \\ up.poznan.pl
}

(Received: January 26, 2015. Accepted: March 31, 2015)

\begin{abstract}
AвSTRACT. This paper presents the macromorphological and micromorphological characteristics of wood barley recorded in the Wielkopolska Lowland. On the basis of the collection of preserved specimens, the micromorphological features were examined under a scanning electron microscope (SEM) to assess their taxonomic value. The principal features include the size and shape of cork/silica cells, crown cells, prickles, macro-hairs and stomata as well as the morphology of long cells in vegetative and reproductive organs.
\end{abstract}

KEY WORDS: Hordelymus europaeus, micromorphological characters, SEM

\section{INTRODUCTION}

Wood barley (Hordelymus europaeus (L.) Jess. ex Harz) is the only species in the genus Hordelymus (Jessen) Harz. This genus is a part of the Agropyron-Elymus complex in the tribe Triticeae (Mizianty \& SzCZEPANIAK 1997). The taxonomic status of perennial genera in the mentioned complex is very controversial (Mizianty et al. 2001). Hordelymus europaeus is an alloploid with two different genomes (von BotнмеR \& JACOBSEN 1989). Analyses of sequence data from plastid genes and single-copy nuclear genes showed close phylogenetic relationships of wood barley with such genera as Psathyrostachys, Pseudoroegneria and Henrardia (Petersen \& Seberg 2008). Similarly, von BотнмеR et al. (1994) postulated a close relationship with Psathyrostachys, whereas Su et al. (2013) suggest that Hordelymus could have directly derived from Critesion while Psathyrostachys produced Critesion.

The taxonomic unclearness is well reflected by the former taxonomic classification of Hordelymus europaeus which resulted from macromorphological observations. It was included in the genus Elymus L. as Elymus europaeus L. (SzAFER et al. 1969, FALKOWSKI et al. 1974), and also in the genus Hordeum as Hordeum europaeum (L.) All. (Humphries 2010), as well as in the genus Cuviera as Cuviera europaea (L.) Koeler
(Humphries 2010) and Leptothrix europaea (L.) Dumort (Clayton et al. 2006).

The profound taxonomic verification of eight species and subspecies in the Agropyron-Elymus complex in Poland was carried out by Mizianty et al. 2001. The study was based on an analysis of many macromorphological and micromorphological traits and confirmed that Hordelymus should be treated as a distinct genus. Studies by WebB \& Almeida (1990) showed that adaxial and abaxial leaf epidermis observed by scanning electron microscopy (SEM) could provide useful taxonomic features in the genera Elymus and Agropyron from the Agropyron-Elymus complex. So far there have been no such observations in Hordelymus europeus. The purpose of this study was to survey epidermal features of vegetative (stems, leaves, sheathes, nodes) and generative (glumes, florets, caryopses) organs of Hordelymus europeus using SEM to see if they provided information of taxonomic value.

\section{MATERIAL AND METHODS}

The samples were collected from two sites in the Wielkopolska Region: from brown-mull Beech wood in Buczyna Forest Subdistrict (16 $\left.58^{\prime} \mathrm{E}, 52^{\circ} 40^{\prime} \mathrm{N}\right)$ and from oak-hornbeam forests in Bytyń Forest Subdistrict $\left(16^{\circ} 28^{\prime} \mathrm{E}, 52^{\circ} 28^{\prime} \mathrm{N}\right)$. 
The fifty most diverse, mature shoots were selected in each site. Four morphological features of these shoots were measured directly in a field: height of a shoot, length of inflorescence, length and width of the middle leaf (see Morphological description section). Afterwards a total of 20 measured shoots (10 shoots from each locality) were collected for further detailed macro- and micromorphological observations.

In macromorphological studies culms, leaves, sheathes, nodes, glumes, florets (lemmas and paleas) and caryopses were analysed. Data were gathered from the adaxial and abaxial surfaces of leaves and the abaxial surface in the middle part and near the margin of the glumes, lemmas and paleas. Examination included measurements of particular parts of the plant (length, sometimes width), description of intensity of pubescence and type of hairs on plant parts as well as observations of many qualitative characters that are fundamental in grass determination (see Morphological description section).

Several micromorphological characters of both long and short cells (cork/silica cells, crown cells, prickles and macro-hairs) and stomata were observed. All were treated as separate characters, although crown cells, prickles and macro-hairs are treated as a single group (exodermic cells) owing to the protrusion of their periclinal wall. The analysed micromorphological characters are summarized in Table 1.

The SEM micrographs were taken with a Zeiss EVO 40 microscope at the Electron and Confocal Microscopy Laboratory, Faculty of Biology, Adam Mickiewicz University of Poznań. Prior to observations the prepared material was sputtered with gold using an SCB 050 ion sputter. The study was documented with photographs taken during observations at the following magnifications: $\times 500, \times 700$ and $\times 10000$ (epicuticular ornamentation). The main characteristics were measured under a light microscope (Olympus BX-43). Stains such as Sudan III were used to aid the identification of cork cells using LM. Samples were sonicated in xylene for at least thirty minutes to remove the epicuticular wax that may obscure surface features (ACEDO \& LLAMAS 2001). In this paper we followed ElLIs (1979) for the description of lemma micromorphology, since lemmas are homologous to leaves (SNow 1996), and extended the terminology to glumes and paleas, because they show similar epidermal characteristics. The terminology of epicuticular waxes follows BARTHLOtT et al. (1998).

The herbarium and carpological material is deposited at the Department of Botany, the Poznań University of Life Sciences (POZNB).

\section{RESULTS AND DISCUSSION}

\section{MORPHOLOGICAL DESCRIPTION OF HORDELYMUS EUROPAEUS FROM TWO LOCALITIES IN THE WIELKOPOLSKA REGION}

At the studied localities specimens of Hordelymus europaeus form fine tufts without stolons. This species is a perennial plant, a hemicryptophyte. Shoots with inflorescences grow $42-128 \mathrm{~cm}$ high. Culms upon the inflorescences are smooth or slightly rough (Fig. 1a). Leaf sheaths are open, slightly expanded, rather densely hairy with stiff and long hairs oriented downwards (Fig. 1b). Upper fragments of sheaths are slightly less hairy. Previous descriptions of wood barley noted that sheaths of leaves located at the lower part of the culm are roughly hairy (SzAFER et al. 1969) and leaf sheaths are slightly hairy (MizIANTY et al. 2001). At the junction of the leaf blade and leaf sheath there is a distinct ligule and small triangular auricles. Ligules are up to $1 \mathrm{~mm}$ in length, forming a membranous rim with flat short hairs. Leaf blades are flat, 4-12 cm long and 8-36 cm wide with long acuminate tips. Upper (adaxial) and lower (abaxial) surfaces of leaf blades are hairy with single, thin and standing hairs. On the abaxial surface trichomes have white keels (Fig. 1b). Nodes are hairy (Fig. 1c). The single and erect raceme is $4-12 \mathrm{~cm}$ long and ca. $1 \mathrm{~cm}$ wide, with densely packed spikelets. According to Clayton et al. (2006) some specimens could have drooping racemes. Spikelets are $13-33 \mathrm{~cm}$ long from the base to the top of the lemma awn and comprise 1-2 fertile florets. A cluster of tree spikelets is located at each node. Glumes are collateral, narrow (max. $19 \mathrm{~mm}$ long with the awn) and connate at the base (Humphries 2010, RutKowski 2011) - Fig. 1d. Veins are hairy with short, stiff hairs, which is in agreement with the previous description by SzAFER et al. (1969). According to Mizianty et al. (2001), glumes are $7-12 \mathrm{~mm}$ (9.8) long and $0.4-1.3 \mathrm{~mm}(0.8)$ wide, with the awn 3.5-0.1 mm (5.8) long. The lemma is lanceolate, 5-veined, ca. $33 \mathrm{~mm}$ long (with the awn, which is about three times longer than the other part of the lemma) and ca. $2 \mathrm{~mm}$ wide, glabrous, but very rough on the veins.

Mizianty et al. (2001) stated that the lemma is 6.5-11.0 mm (9.6) long with a very long awn of 6-29 $\mathrm{mm}$ (19.5), i.e. twice as long as the lemma. SzAFER et al. (1969) reported that the lemma is glabrous. The palea is narrowly elliptical, 2-keeled, with a sharp tip, as long as the lemma and slightly longer than the caryopsis. The rachilla is ca. $5 \mathrm{~mm}$ long. The caryopsis is 7-7.5 mm long and $2 \mathrm{~mm}$ wide, narrowly lanceolate; compression is dorsiventral, strong; the dorsal face somewhat rounded; lateral ridges conspicuous, sulcus depth medium to deep, width medium, corona $0.5-1 \mathrm{~mm}$ long; apical hairs sparse to dense, length 
short to medium; the embryo is $1 / 5-1 / 6$ of the caryopsis length.

\section{MICROMORPHOLOGICAL DESCRIPTION OF HORDELYMUS EUROPAEUS}

\section{STEM, LEAF SHEATHS AND NODE SURFACE (FIG. 1)}

Long cells were the dominant elements on the epidermal surfaces of the stem. These cells were elongated axially (parallel with the long axis). The anticlinal walls were generally straight, while the periclinal walls were convex. Short cells were absent. Stomata with parallel-shaped subsidiary cells formed one row. Cork/silica cells were not observed. Crown cells were commonly observed in this surface, and in the lateral view they were hook-shaped (Fig. 1a). In leaf sheaths a heterogeneous surface was found (Fig. 1b) and long cells were dominant elements of the intercostal areas. The rectangular costal long cells were shorter than the intercostal long cells. Stomata with parallel-shaped subsidiary cells formed one-two rows in the intercostal areas. Crown cells and cork/ silica cells were commonly observed in this surface.
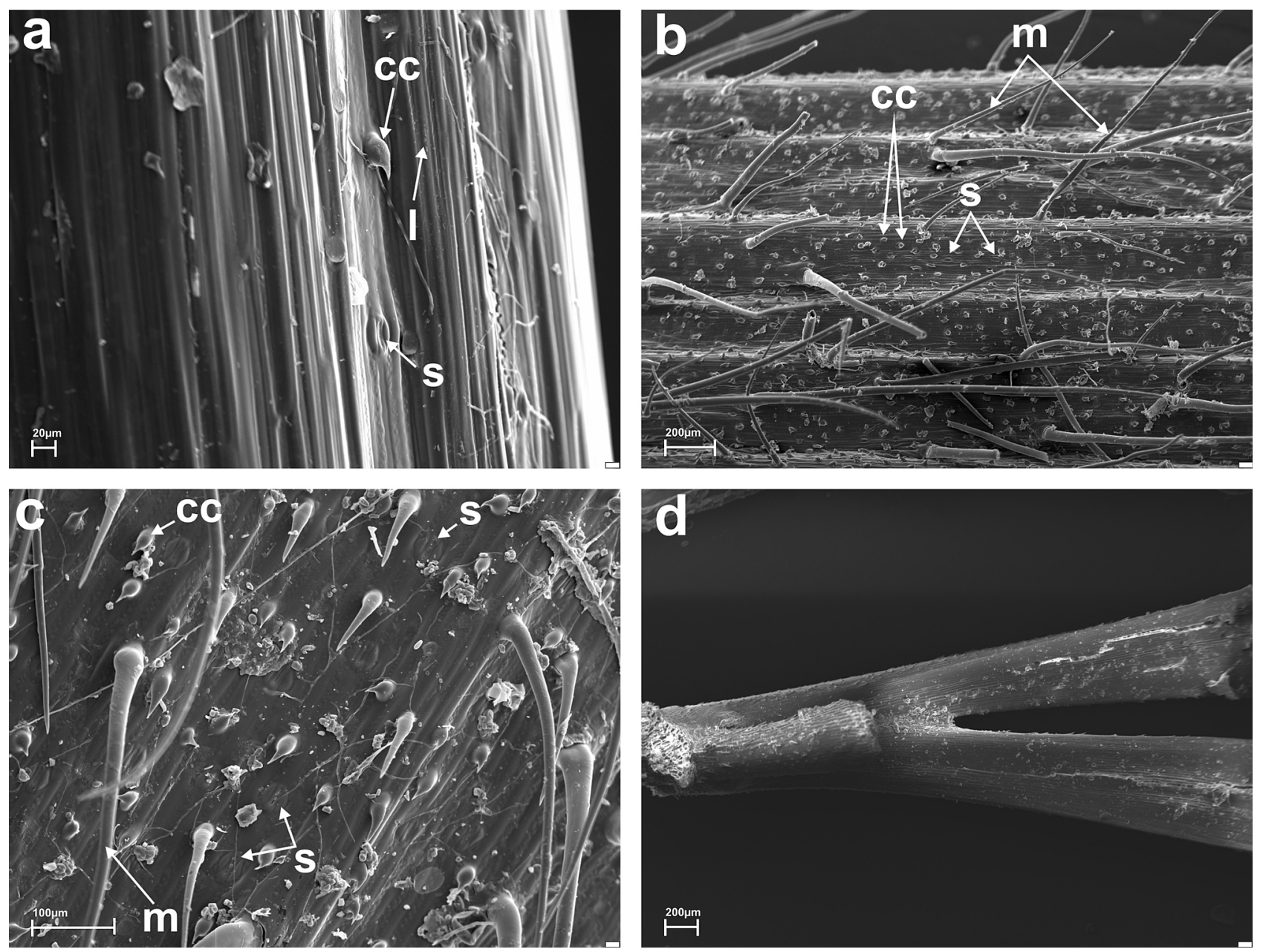

Fig. 1. SEM. Micromorphology of epidermis in Hordelymus europaeus: a - culm, b - leaf-sheath, c-nodus, d - glumes connate at the base

Abbreviations: $\mathrm{cc}$ - crown cells, 1 - long cells, $\mathrm{m}$ - macro-hairs, $\mathrm{s}$ - stomata.
The leaf sheath surface is covered by macro-hairs of varied length in costal and intercostal areas (Fig. 1b). The node surface was heterogeneous, and macro-hairs of varied length, crown cells and cork/silica cells were dominant elements of the epidermal surface. The long cells were elongated axially (parallel with the long axis). The anticlinal walls were generally straight, while periclinal walls were convex or flat. Stomata with parallel-shaped subsidiary cells formed one row (Fig. 1c).

\section{ADAXIAL LEAF-BLADE SURFACE (TABLE 1, FIGS. 2A, 3A)}

In Hordelymus europaeus a heterogeneous adaxial leaf-blade surface was observed (Fig. 2a). Epicuticular waxes were found in the form of platelets (Fig. $3 a)$. Long cells were dominant elements of the epidermal leaf surfaces. These cells were elongated axially (parallel with the long axis). The rectangular costal long cells were shorter than the intercostal long cells. The anticlinal walls were generally straight, irregularly thickened. Periclinal walls were convex or flat. Short cells were absent. Stomata with parallel-shaped and dome-shaped subsidiary cells formed 
Table 1. The principal micromorphological characteristics of Hordelymus europaeus

\begin{tabular}{|c|c|c|c|c|}
\hline Feature & \multicolumn{2}{|c|}{ Adaxial leaf-blead surface } & \multicolumn{2}{|c|}{ Abaxial leaf-blead surface } \\
\hline Type of surface & \multicolumn{2}{|c|}{ heterogeneous } & \multicolumn{2}{|c|}{ heterogeneous } \\
\hline Epicuticular wax & \multicolumn{2}{|l|}{ platelets } & \multicolumn{2}{|c|}{ platelets } \\
\hline \multicolumn{5}{|l|}{ Stomata } \\
\hline \multirow{2}{*}{$\begin{array}{l}\text { Stomata length }(\mu \mathrm{m}) \\
\text { Shape of subsidiary cells }\end{array}$} & \multirow{3}{*}{\multicolumn{2}{|c|}{$\begin{array}{l}30.42-49.61 \\
\text { parallel-shaped, dome-shaped } \\
\text { aligned in } 1-2 \text { rows }\end{array}$}} & \multicolumn{2}{|c|}{$26.14-39.61$} \\
\hline & & & parallel & aped \\
\hline Frequency & & & aligned & 1 row \\
\hline Long cells & & & & \\
\hline Shape & \multicolumn{2}{|c|}{ elongate or rectangular } & \multicolumn{2}{|c|}{ elongate or rectangular } \\
\hline Anticlinal walls & \multicolumn{2}{|c|}{ straight or slightly thickened, raised } & \multicolumn{2}{|c|}{ straight or slightly undulate, raised } \\
\hline Periclinal walls & \multicolumn{2}{|c|}{ flat, convex } & \multicolumn{2}{|c|}{ flat, convex } \\
\hline Short cells & \multicolumn{2}{|l|}{ absent } & \multicolumn{2}{|l|}{ absent } \\
\hline Cork/silica cells & \multicolumn{2}{|l|}{ absent } & \multicolumn{2}{|l|}{ absent } \\
\hline Crown cells diameter $(\mu \mathrm{m})$ & \multicolumn{2}{|c|}{$33.29-53.78 \times 21.2-26.6$} & \multicolumn{2}{|c|}{$30.19-1.77 \times 15.05-25.43$} \\
\hline Macrohairs & \multicolumn{2}{|c|}{ present } & \multicolumn{2}{|l|}{ present } \\
\hline Feature & Abaxial glume surface & \multicolumn{2}{|c|}{ Abaxial lemma surface } & Abaxial palea surface \\
\hline Type of surface & & \multicolumn{2}{|c|}{ heterogeneous } & homogeneous \\
\hline Epicuticular wax & platelets & \multicolumn{2}{|c|}{ platelets, irregular crystalloid } & irregular crystalloid \\
\hline \multicolumn{5}{|l|}{ Long cells } \\
\hline length $(\mu \mathrm{m})$ & $111.6-219.7$ & \multicolumn{2}{|l|}{$36.8-111.3$} & $28.8-54.5$ \\
\hline Shape & rectangular & elongate to rec & & rectangular \\
\hline Anticlinal walls & undulate & undulate & & undulate \\
\hline Periclinal walls & convex & convex & & convex \\
\hline Stomata length $(\mu \mathrm{m})$ & $35.5-43.1$ & $29.1-41.9$ & & $37.5-41.2$ \\
\hline $\begin{array}{l}\text { Cork / silica cells diameter } \\
(\mu \mathrm{m})\end{array}$ & $13.3-18.4 \times 12.1-17.9$ & $12.5-20.3 \times 1$ & & $12.1-18.4 \times 14.1-19.6$ \\
\hline Crown cells diameter $(\mu \mathrm{m})$ & $14.5-24.5 \times 12.0-21.0$ & $19.0-30.2 \times 1$ & & $13.3-21.4 \times 13.3-25.6$ \\
\hline Prickles & present & present & & absent \\
\hline Macrohairs & absent & absent & & absent \\
\hline
\end{tabular}

one-two rows in the intercostal areas. The length of stomata varied from 30.4 to $49.6 \mu \mathrm{m}$. Silica bodies were not observed. Different terms have been used for 'crown cells', previously proposed by PRAT (1932) and revised by WATSON \& DaLLWITZ (1988). Later MEJiA-SAules \& Bisby (2003) used 'hooked papilla'. In our study we adopted the first proposed term 'crown cells', similarly as OrTúÑEz and de la FuENTE (2010) and KLIMKo et al. (2009). Crown cells with a pointed apex were commonly observed in this surface and their size was 33.3-53.7 × 21-26 $\mu \mathrm{m}$ (Table 1). In the lateral view they were hook-shaped. Simple macro-hairs were found (Fig. 2a).

\section{ABAXIAL LEAF-BLADE SURFACE (TABLE 1, FIG. 2B)}

The abaxial leaf-blade surface was similar to the adaxial leaf-blade surface. The anticlinal walls were straight or slightly undulate. Stomata with parallel-shaped subsidiary cells formed one row near the leaf margins; they were less numerous and shorter than on the adaxial leaf-surface blade. Stomata length ranged from 26.1 to $39.6 \mu \mathrm{m}$. Cork/silica cells were not observed. Crown cells generally rounded, with a pointed apex, commonly observed in this surface, varied in diameter (Table 1). Crown cells were short- er than on the adaxial leaf-blade surface. In both surfaces protrusion of crown cells was formed by most of the external periclinal cell wall. Macro-hairs were found over the costal and intercostal zones and the leaf margin (Fig. 2b). Our results differ from those of Su et al. (2013) with respect to presence of stomata and macro-hairs on the abaxial epidermis.

\section{ABAXIAL GLUME SURFACE (TABLE 1, FIGS 2C, 3B)}

The glume surface was homogeneous with epicuticular wax platelets (Fig. 3b). The dominant elements in this surface were long cells, crown cells and cork/silica cells. Rectangular to elongated long cells with convex periclinal walls and highly undulate anticlinal walls were observed (Fig. 2c). Cork/silica pair cells were $13.3-18.4 \times 12.1-17.9 \mu \mathrm{m}$ in diameter. Crown cells were commonly observed in this surface. They varied in diameter, ranging from 14.5 to $24.5 \mu \mathrm{m}$ in length and from 12.0 to $21.0 \mu \mathrm{m}$ in width. Protrusion of crown cells was formed by most of the external periclinal cell wall. Paracytic stomata (near the margin) were observed, ranging in length from 35.5 to $43.21 \mu \mathrm{m}$. Prickles had thick walls, elongate or oval bases, a pointed apex, and they were oriented with the tip directed to the glume apex (Fig. 2c). 

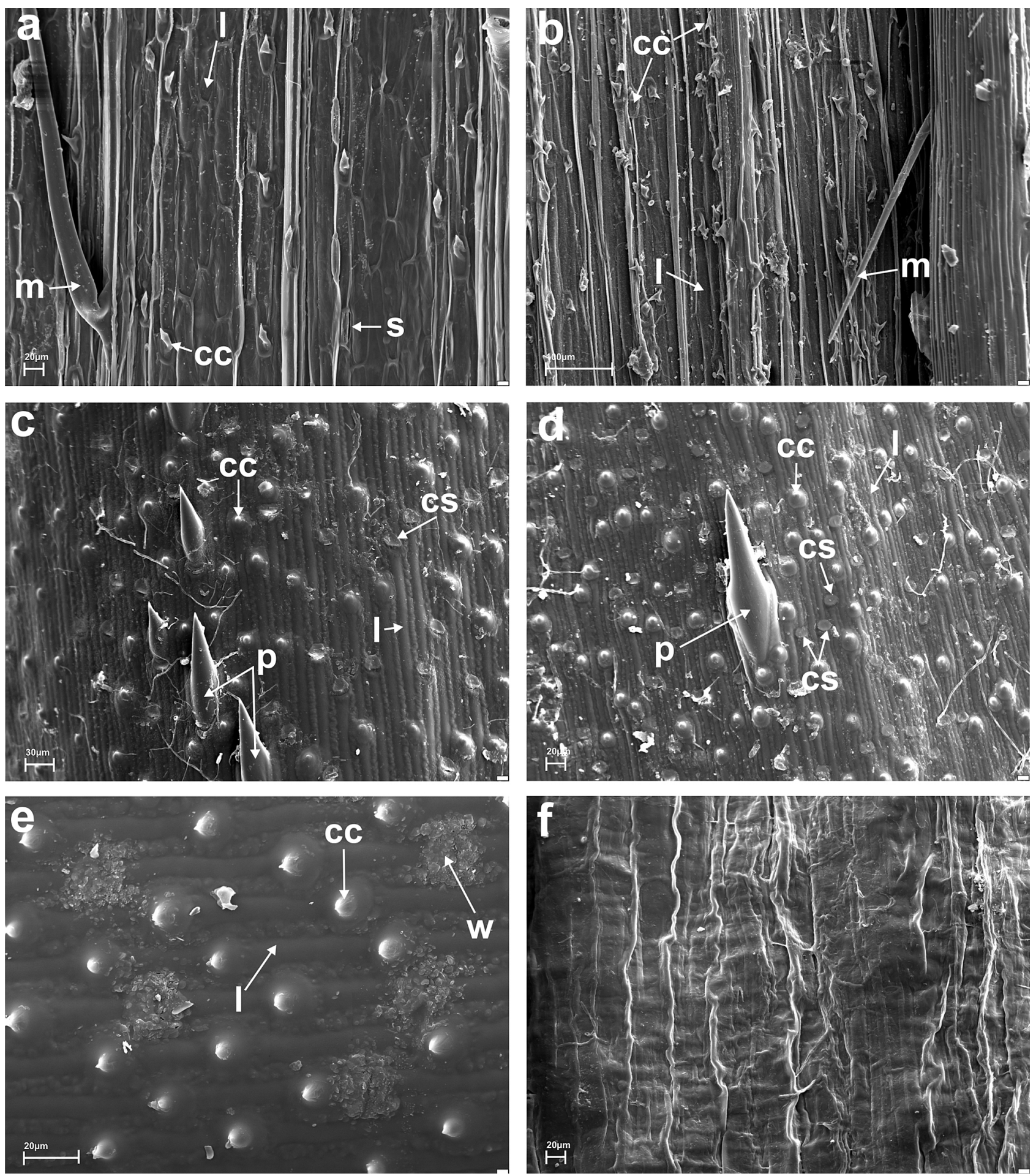

Fig. 2. SEM. Micromorphology of epidermis in Hordelymus europaeus: a - adaxial leaf-blade, b - abaxial leaf-blade, c - abaxial glume epidermis, $\mathrm{d}$ - abaxial lemma epidermis, e - abaxial palea epidermis, $\mathrm{f}-$ adaxial caryopsis epidermis Abbreviations: $\mathrm{cc}$ - crown cells, cs - cork/silica cells, 1 - long cells, $\mathrm{m}$ - macro-hairs, $\mathrm{p}$ - prickles, $\mathrm{s}$ - stomata, $\mathrm{w}$ - wax.

\section{ABAXIAL LEMMA SURFACE}

(TABLE 1, FIGS 2D, 3C)

Lemma epidermis was heterogeneous with epicuticular waxes of the crystalloid type (difficult to describe), corresponding to the adaxial palea surface and platelets similar as on the glume surface (Fig. 3c). The lemma surface showed differences between epidermis over the veins and the rest of the epider- mis surface (Fig. 2d). The dominant elements in this surface were long cells, crown cells and cork/silica cells. Rectangular to elongated long cells with convex periclinal walls and highly undulate anticlinal walls were observed (Fig. 2d). Two types of short cells were recognized: cork and silica cells (Fig. 2d). These cells were oval or rounded in shape. Cork/silica pair cell diameter was $12.5-20.3 \times 16.7-23.96 \mu \mathrm{m}$. Crown 

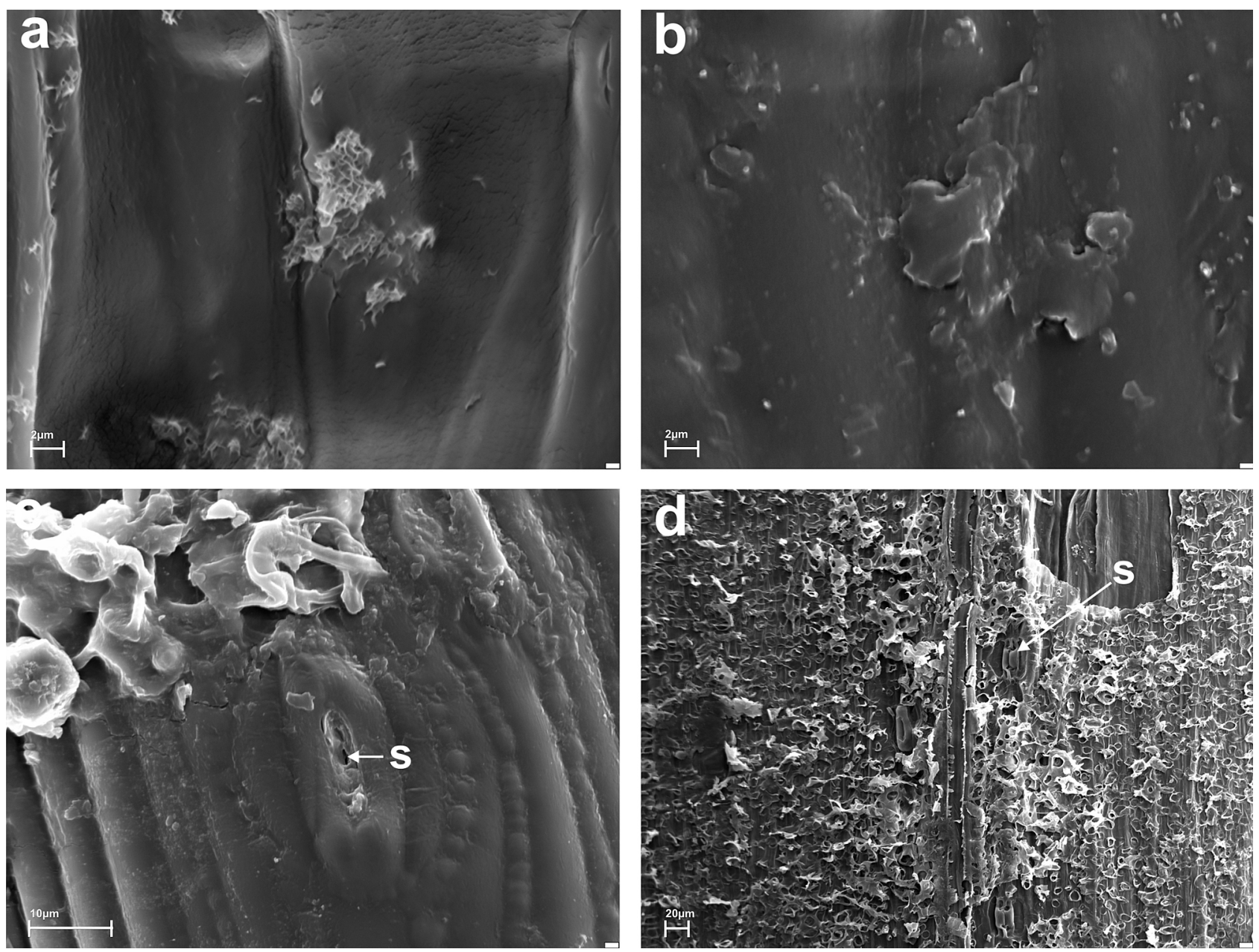

Fig. 3. SEM. Wax ornamentation in Hordelymus europaeus: a - adaxial leaf-blade epidermis, b - abaxial glume epidermis, $\mathrm{c}$ - abaxial lemma epidermis, $\mathrm{d}$ - abaxial palea epidermis Abbreviations: $\mathrm{s}$ - stomata.

cells were commonly observed in this surface. They varied in diameter and ranged from 19.0 to $30.26 \mu \mathrm{m}$ in length and from 16.7 to $27.56 \mu \mathrm{m}$ in width. Crown cell size on the lemma surface was greater than on glumes and the palea surface. Paracytic stomata were observed and their length ranged from 29.1 to 41.96 $\mu \mathrm{m}$. Prickles with oval bases and with a pointed apex were found.

\section{ABAXIAL PALEA SURFACE (TABLE 1, FIGS 2E, 3D)}

The palea epidermis was homogeneous with crystalloid epicuticular waxes (Fig. 3d), corresponding to the abaxial lemma surface (Fig. 3c). The dominant elements in this surface were long cells, crown cells and cork/silica cells. Rectangular to elongated long cells with convex periclinal walls and highly undulate anticlinal walls were observed. The long cells were markedly shorter than on the lemma surface (Table 1). Cork/silica pair cell diameter was 12.1-18.4 $\times$ 14.1-19.6 $\mu \mathrm{m}$. The shape was similar as in glumes and lemmas. Crown cells were commonly observed in this surface (Fig. 2e). They varied in diameter and ranged from 13.3 to $21.4 \mu \mathrm{m}$ in length and from 13.3 to $25.6 \mu \mathrm{m}$ in width. Paracytic stomata aligned in 1 row were observed and their length ranged from 37.5 to $41.2 \mu \mathrm{m}$. The minimum value of this trait was greater than on the lemma surface. Prickles were absent (Fig. 2e).

\section{CARYOPSIS SURFACE (FIG. 2F)}

The outer dorsal surface of the caryopsis was irregularly reticulate. Crystalloid wax was absent. The anticlinal walls were raised, thickened, slightly undulate. These cells were elongated axially (parallel with the long axis). Periclinal walls were concave or irregularly folded. Short cells were absent (Fig. 2f).

\section{CONCLUSION}

The results of SEM examinations confirm the taxonomic significance of the micromorphological characters in the genus Hordelymus (Mizianty et al. 2001). The principal features of taxonomic value in leaf, glume and floret surfaces include the shape, size and distributions of prickles, macro-hairs, cork/silica cells, crown cells, as well as the shape and diameter of long cells and stomata. Elongated intercostal 
and rectangular costal long cells were common in the heterogeneous leaf-blade, leaf-sheath and lemma surfaces. Long cells of glumes and paleas were usually rectangular. These cells have convex periclinal walls. In contrast, the anticlinal walls are parallel, with straight walls, irregularly thickened in the leaf blades, and highly sinuous, $\Omega$-shaped in glumes, lemmas and paleas. Cork/silica cells, crown cells and prickles have relatively uniform shapes. Epicuticular wax is formed by crystalloids of different thickness. Our study shows that the micromorphology of the abaxial leaf surface and the abaxial surface of glumes, lemmas and paleas is the most important, while the principal diagnostic characters are their size and shape as well as their presence or absence.

\section{ACKNOWLEDGEMENTS}

We would like to express our gratitude to Wojciech Klimko for his assistance with computer data records. We would also like to thank Mr. Richard Ashcroft for his helpful comments on the usage of English in this paper. The authors would like to thank anonymous reviewers for their suggestions and comments made on an earlier version of the manuscript. The study was supported by the Department of Botany, the Poznań University of Life Sciences.

\section{REFERENCES}

Acedo C., Llamas F. (2001): Variation of micromorphological characters of lemma and palea in the genus Bromus (Poaceae). Annales Botanici Fennici 38: 1-14.

Barthlott W., Neinhuis C., Cutler D., Ditsch F., Meusel I., Theisen I., Wilhelmi H. (1998): Classification and terminology of plant epicuticular waxes. Botanical Journal of Linnean Society 126: 237-260.

von BOtHMER R., JACOBSEN N. (1989): Intergeneric hybridization between Hordeum and Hordelymus (Poaceae). Nordic Journal Botany 9: 113-117.

von Bothmer R., Lu B-R., Linde-Laursen I. (1994): Intergeneric hybridization and C-banding patterns in Hordelymus (Triticeae, Poaceae). Plant Systematics and Evolution 189: 259-266.

Clayton W.D., Vorontsova M.S., Harman K.T. and Williamson H. (2006 onwards): GrassBase - The Online World Grass Flora. http://www.kew.org/ data/grasses-db.html [access: November 2006; 15:30 GMT].

ELLIS R.P. (1979): A procedure for standardizing comparative leaf anatomy in the Poaceae I. The epidermis as seen in surface view. Bothalia 12(4): 641-671.

Falkowski M., Filipek J., Filipek M., Grynia M., Rudnicka-Sterna W., Rutkowska B., Szoszkiewicz J.
(1974): Trawy uprawne i dziko rosnące. PWRiL, Warszawa.

Humphries C.J. (2010): Hordelymus (Jessen) C.O. Harz. In: T.G. Tutin, V.H. Heywood, N.A. Burges, D.M. Moore, D.H. Valentine, S.M. Walters, D.A. Webb (eds). Flora Europaea. Vol. 5. Alismataceae to Orechidaceae. Cambridge University Press, Cambridge: 205.

Klimko M., Pudelska H., WojciechowsKa B., Klimko W. (2009): Variation of micromorphological characters of lemma and palea in Aegilops kotschyi and Aegilops biuncialis $\times$ Secale cereale hybrids, amphiploids and parental forms. Roczniki Akademii Rolniczej w Poznaniu 388, Botanika-Steciana 13: 167-176.

Mejia-Saules T., Bisby F.A. (2003): Silica bodies and hooked papillae in lemmas of Melica species (Gramineae: Pooideae). Botanical Journal of Linnean Society 141: 447-463.

Mizianty M., Frey L., Szczepaniak M. (2001): The Agropyron-Elymus complex (Poaceae) in Poland: biosystematics In: L. Frey (ed.). Studies on the grasses in Poland. W. Szafer Institute of Botany, Polish Academy of Sciences, Kraków: 25-77.

Mizianty M., SzcZepaniaK M. (1997): Remarks on the Agropyron-Elymus complex (Poaceae) with special reference to its representatives in Poland. Fragmenta Floristica et Geobotanica 42 (2): 215-225.

OrtúÑEZ E., dE LA Fuente V. (2010): Epidermal micromorphology of the genus Festuca L. (Poaceae) in the Iberian Peninsula. Plant Systematic and Evolution 284: 201-218.

Petersen G., Seberg O. (2008). Phylogenetic relationships of allotetraploid Hordelymus europaeus (L.) Harz (Poaceae: Triticeae). Plant Systematics and Evolution 273: 87-95.

Prat H. (1932): L'epiderme des Graminées: ètude anatomique et systèmatique. Annales des Sciences Naturelles Sèrie Botanique. 14: 117-324.

RutKowski L. (2011): Klucz do oznaczania roślin naczyniowych Polski Niżowej. Wyd. Nauk. PWN, Warszawa.

Snow N. (1996): The phylogenetic utility of lemmatal micromorphology in Leptochloa s.l. and related genera in subtribe Eleusininae (Poaceae, Chloridoideae, Eragrostideae). Annals of the Missouri Botanical Garden 83: 504-529.

Su X., Liu Y.P., Chen K.L. (2013): Biosystematic relationships among Psathrostachys, Critesion and Hordelymus in Hordeinae (Poaceae) based on the anatomical characteristics of leaf blades. African Journal of Plant Science 7 (8): 384-393.

SZAFER W., KulczYŃsKi S., PAWŁowsKi B. (1969): Rośliny polskie. PWN, Warszawa.

Watson L., Dallwitz M.J. (1988): Grass genera of the world. Illustration of characters, classification, interactive identification, information retrieval. 
Research School of Biological Sciences, Australia National University, Canberra.

Webi M.E., Almeida M.T. (1990): Micromorphology of the leaf epidermis in taxa of the Agropyron-Elymus complex (Poaceae). Botanical Journal of the Linnean Society 103 (2): 153-158.
For citation: KLIMko M., NowińskA R., Czarna A. (2015): Epidermal micromorphology of Hordelymus europaeus (L.) Jess. ex Harz (Poaceae). Steciana 19(2): 89-96. DOI 10.12657/steciana.019.010 